\title{
Review of the species from the order Solifugae (Arachnida) in the collection of the Institute of Zoology of the Azerbaijan National Academy of Sciences, Baku
}

\section{Обзор видов из отряда Solifugae (Arachnida) в колмекщии Института зоологии НАН АзербайАжана (Баку)}

\author{
Kh.A. Aliyev, N.E. Novruzov, Kh.A. Nabiyeva \\ Х.А. Алиев, Н.Э. Новрузов, Х.А. Набиева
}

Institute of Zoology of National Academy of Sciences of Azerbaijan, passage 1128, district 504, Baku AZ 1073 Azerbaijan. E-mail: khalidaliyev@mail.ru

Институт зоологии НАН Азербайджана, проезд 1128, квартал 504, Баку AZ 1073 Азербайджан.

KEY WORDS: camel spider, Solifugae, species, distribution, station.

КЛЮЧЕВЫЕ СЛОВА: сольпуга, Solifugae, вид, распространение, стация.

ABSTRACT. The order Solifugae in the collection of the Institute of Zoology, Baku is represented by 13 species from seven genera and five families. Detailed accounts are provided concerning their habitats and overall distribution in Azerbaijan.

How to cite this article: Aliyev Kh.A., Novruzov N.E., Nabiyeva Kh.A. 2018. Review of the species from the order Solifugae (Arachnida) in the collection of the Institute of Zoology of the Azerbaijan National Academy of Sciences, Baku // Arthropoda Selecta. Vol.27. No.3. P.257-259. doi: 10.15298/arthsel. 27.3.10

РЕЗЮМЕ. Отряд сольпуги (Solifugae) представлен в коллекции Института зоологии, Баку 13 видами из семи родов и пяти семейств. Приведены детальные сведения об их биотопах и общему распространению в Азербайджане.

\section{Introduction}

The camel-spider order Solifugae contains more than 1,000 species. Of these, 70 species occur in the territory of the former USSR, including 11 species in the fauna of Azerbaijan [Birula, 1938; Aliyev, Hajiyev, 1983; Aliyev, 1984; Hajiyev, 1996].

The material presented below was collected in various parts of the Republic of Azerbaijan between 1976 to 2018 by Sh. Aliyev, E. Huseynov, Sh. Magerramova and the authors. Species identifications were carried out using the monographs of Byalynitskiy-Birula [1938] and Turk [1960], partly compared also with the collection of the Zoological Institute of the Russian Academy of Sciences, St. Petersburg, Russia (ZIN). The species were identified either by Sh. Aliyev or S. Dashdamirov. Information concerning the distribution of species is based on literature data [Birula, 1938; Aliyev, 1984; Hajiyev, 1996; Gromov, 1998].
The present paper provides an annotated list of 13 species of the Solifugae kept in the collection of the Institute of Zoology, Azerbaijan National Academy of Sciences, Baku (IZBA).

\section{List of species}

Family Rhagodidae Pocock, 1897

Genus Rhagodes Pocock, 1897

Rhagodes caucasicus Birula, 1893

MATERIAL. No-90. $1 \sigma^{7}$, Azerbaijan, Nakhchivan, Julfa, 26.VI.[19]78; 1 O$^{7}$, same locality, 28.VI.[19]78, all leg. Sh. Aliyev.

DISTRIBUTION. Southern Transcaucasia from the valley of Arax River to the right bank of Kura River near Kirovobad (now Ganja) [Birula, 1938]. Azerbaijan (Nakhchivan) [Hajiyev, 1996].

REMARKS. Females are larger than males, but the pedipalps and all four pairs of legs are much longer in males. The distribution covers the southern slopes of the Caucasus Minor within Nakhchivan, inhabiting the wormwood grasslands on the slopes of hills [Aliyev, 1984].

Family Karschiidae Kraepelin, 1899

Genus Karschia Simon, 1880

Karschia caucasica (C.L. Koch, 1878)

MATERIAL. No-37. $2 \sigma^{7} \sigma^{7}$, Azerbaijan, Baku, 24.V.[19]76, leg. Sh. Aliyev.

DISTRIBUTION. Azerbaijan (Absheron) [Birula, 1938; Aliyev, 1984].

REMARKS. Endemic to Azerbaijan. Both specimens were found in the area of new construction sites within the city of Baku [Aliyev, 1984].

Karschia mastigophora Birula, 1890

MATERIAL. No-156. 1 ơ, Azerbaijan, Shakhbuz, near Bichenek, 25.VIII.[19]80; No-100. $1 \overbrace{}^{7}$, Karabakh, Fizuli, 26.05. [19]79; No-94. 1 +, Gandja, 26.V.[19]80; No-106. 1 9, Lerik, 18. VIII. [19]80; No-68. 1 \%', Shakhbuz, 25.VI.[19]78, all leg. Sh. Aliyev; No-129. 1 +, Lenkoran (Talysh), 2002, leg. E. Huseynov.

DISTRIBUTION. Caucasus Minor. Azerbaijan, Armenia, Iran [Birula, 1938]. 
REMARKS. Within Azerbaijan, this species occurs on the northern and southern slopes of the Caucasus Minor, the mountain steppes of Talysh Mountains and in the Arax Lowland. In the foothills of the Caucasus Minor, it occupies wormwood ephemeral habitats, in the Talysh Mts the belt of highland xerophytes. Found under stones in shallow burrows [Aliyev, 1984].

\section{Family Gylippidae Roewer, 1933}

Genus Gylippus Simon, 1879

Gylippus caucasicus Birula, 1907

MATERIAL. No-103. 1 + , Azerbaijan, Lerik, 14.08.[19]80 leg. Sh. Aliyev.

DISTRIBUTION. Caucasus Minor, Azerbaijan (Talysh) [Birula, 1938; Hajiyev, 1996].

REMARKS. The distribution of this species covers the southern and northern slopes of the foothills of the Caucasus Minor and the Talysh Mountains. A typical inhabitant of xerophilic habitats. In the foothills of the Caucasus Minor, the activity is twilight and nocturnal, whereas in the highland steppes it is active during the daytime.

\section{Family Daesiidae Kraepelin, 1899}

Genus Daesia Karsch, 1880

Daesia shelkovnikovi Birula, 1936

MATERIAL. No-91. 2 O $^{7} 0^{7}$, Azerbaijan, Nakhichevan, [19]79, leg. Sh.Aliyev.

DISTRIBUTION. Azerbaijan (Nakhichevan) [Aliyev, 1984; Hajiyev, 1996].

REMARKS. The species has been described from males alone, while females still remain unknown. In Azerbaijan, it is distributed exclusively in Nakhichevan. A typical inhabitant of semi-desert, occurring in vineyards, river floodplains and virgin lands. Found mainly under stones.

Genus Gluviopsis Roewer, 1933

Gluviopsis nigrocinctus (Birula, 1905)

MATERIAL. No-89. 1 O$^{7}$, Azerbaijan, Nakhchivan, [19]79, leg. Sh. Aliyev.

DISTRIBUTION. Middle Asia, Turkmenia, Iran [Birula, 1938; Gromov, 1998], Azerbaijan [Aliyev, 1984].

REMARKS. The species has been described from Central Asia [Birula, 1938]. In the Caucasus, it was first discovered in Azerbaijan by Sh. Aliev [1985]. The individuals from Azerbaijan are noticeably smaller than Central Asian specimens. In Azerbaijan, the numbers of this species are small [Aliyev, 1984].

\section{Family Galeodidae Sundevall, 1833}

Genus Galeodes Olivier, 1791

Galeodes araneoides (Pallas, 1772)

MATERIAL. No-53. 1 \%, 8 O $^{7} \sigma^{7}$, Azerbaijan, Djebrail, near Veysalli, 17.VII.[19]78; No-44. 1 + , Fizuli, near Kurdlar, 2.VII. [19]76; No-50. 1 ㅇ, Apsheron, 17.VII.[19]76; No-75. 4 우, 6 juv., Lachin, 19-20.VIII.[19]78; No-69. 4 우, Djebrail, near Gumbag, 20.VII.[19]78; No-147. 3 우, 1 O', Lerik, 18.VIII.[19]80; No-55. 1 9, Shakhbuz, near Bichenek, 18.VIII.[19]79; No-102. 1 \%, Apsheron, Shuvelyan, 20.VII.[19]76; No-81. 4 o+9, Fizuli, near Gochakhmedly, 28-31.VII.[19]78; No-78. 11 우, Gubadly, near Giyasly, 15-23.VII.[19]78; 1 , $3 \mathrm{O}^{\top} \mathrm{O}^{7}$, Lerik, near Gosmalyan, 1-15.07. [19]79; No-85. 2 + , Imishli, near Sarchanli, 30. VIII. [19]78; 1 5 juv., Jebrail, 17.VIII.[19]78; 3 우, Julfa, 24.VIII.[19]77; 8 우, Jebrail, near Gumlag, 27-30.VIII.[19]78; No-54. 1 o, Apsheron, near Nardaran, 20.IV.1977; No-101. 1 \%, Fizuli, near Garamamed, 26.V.[19]79, all leg. Sh. Aliyev; No-153. 3 +, Lerik, Zuvand, VII

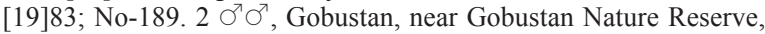

18.VII.2012; No-200. 1 ㅇ, same locality 2.X.2012, all leg. N. Novruzov; No-208. 3 우, 1 O$^{7}$, Fizuli, near Goradis, 6.VII.2016, leg. Sh. Magerramova, Kh. Aliyev; No-210. 1 +, 2 juv., Gobustan, 15-19.VI.2018, leg. N. Novruzov.

DISTRIBUTION. This species is widespread from North Africa to Central Asia. According to modern information, the range of this species extends from the Lower Dnieper and the Crimean Peninsula in the west to the valley of Ural River in Kazakhstan in the east, and from the the Middle Volga area in the north to the Caucasus Minor, Armenian Upland and northern Iran in the south, covering several natural zones [Birula, 1912; Byalynitsky-Birula, 1938]. In the south, the range covers the Caucasus Minor, Armenia, Azerbaijan and northern Iran [Birula, 1938; Hajiyev, 1996].

REMARKS. This species is widespread throughout the lowland parts of Azerbaijan. In the Caucasus Minor, it inhabits the northern, southern and southeastern slopes up to subalpine meadows. In the Caucasus Major, the northern border runs along the foothill belt. Abundant in the Absheron Peninsula and the Kura Lowland. Successful in anthropogenic habitats, readily coming to artificial light.

Galeodes armeniacus Birula, 1928

MATERIAL. No-80. 14 우, Azerbaijan, Jebrail, near Gumlag, 27.VIII.[19]78; 1 ㅇ, same locality, 30.VIII.[19]78; No-79. 1 \%, Jebrail, near Veysalli, 17.VIII.[19]78; $1 \sigma^{7}$, same locality, 19.VII. [19]78; No-70. 3 of , Julfa, 04.VII.[19]78; 1 , same locality, 25. VII.[19]77; 3 우, same locality, 24.VIII.[19]77; $1 \mathrm{O}^{\text {}}$, same locality, 24.08.[19]79; No-62. 2 우, $1 \mathrm{O}^{7}$, Ilyichovsk (now Sharur), near Khok, 28.VI.[19]78; No-73. 5 of , 2 O$^{7} \Im^{7}$, Nakhichevan, near Negram, 15-20.VI.[19]78; No-63. 1 , 1 ○', Ordubad, near Dasta, 19.VI.[19]78, all leg. Sh. Aliyev.

DISTRIBUTION. Caucasus Minor, Armenia, Azerbaijan, Iran [Hajiyev, 1996].

REMARKS. One of the most abundant species, within Nakhichevan a background one. It tends to expand its distribution northward along the southeastern slopes of the Caucasus Minor, approaching the border of the Kura-Arax Lowland. It easily settles in rodent holes.

Galeodes caspius Birula, 1890

MATERIAL. No-98. 2 O$^{7} \sigma^{7}$, Azerbaijan, Apsheron, 1980, leg. Sh. Aliyev; No-132. 1 O$^{7}$, Apsheron, near Bina, 5-11.VII.1987, leg. N. Novruzov.

DISTRIBUTION. Middle Asia, Caucasus Minor, Iran [Birula, 1938], Azerbaijan (Absheron) [Aliyev, 1984; Hajiyev, 1996].

REMARKS. The distribution of this species within Azerbaijan covers the Absheron Peninsula and the semi-desert zone on the southern slopes of the Caucasus Minor. Specimens from Azerbaijan are much smaller than Central Asian individuals. In Azerbaijan, G. caspius is ranked among not too abundant species [Aliyev, Hajiev, 1983].

Galeodes nachitschevanicus Aliyev, 1985

MATERIAL. No-107. 20 오, $40^{7} \sigma^{7}, 15$ juv., (Holotype $0^{7}$, IZBA, Locality: Azerbaijan, Nakhichevan, Shakhbuz, $39^{\circ} 24^{\prime}$ N; $45^{\circ} 34^{\prime} \mathrm{E}$, Sh. Aliev). All this material is temporarily kept in the private collection of Sh. Aliev.

DISTRIBUTION. Azerbaijan (Nakhichevan, Shakhbuz) [Aliyev, 1985].

REMARKS. This species occurs in clayey areas, on stony slopes, in mountain and foothill steppes, at forest edges, in wormwood and grass semi-desert habitats. It is widespread at altitudes from 700 to $2000 \mathrm{~m}$ a.s.l. The species is close to $G$. araneoides, but differs by the smaller overall size, the coloration, the number of denticles on the 
chelicerae, the shapes of the bacillus and the sole on the tarsus of $\sigma^{7}$ leg-pair IV [Aliyev, 1985].

Galeodes turcmenicus Birula, 1937

MATERIAL. No-123. 3 ㅇ, Azerbaijan, Julfa, near Arafsa, 25.VIII.[19]79; No-66. 1 \%, Shakhbuz, near Garatay, 29.VI.[19]78; No- 65. 2 우, Shakhbuz, near Bichenek, 18.VIII.[19]78; 1 q same locality, 25.VIII.[19]80; 1 + , same locality, 29.VI.[19]78; No-117. 3 우, Ordubad, 16.VI.[19]78; 4 우, $1 \bigcirc^{7}$, Julfa, near Tollari, 23.VI [19]78; No-86. 4 oㅇ, Shakhbuz, near Enikend, 19.VI.[19]78; No121. 2 우, Ordubad, near Nesrivas, 25.VI.1984, all leg. Sh. Aliyev. 1998].

DISTRIBUTION. Turkmenia [Birula, 1938; Gromov,

REMARKS. Morphologically, this species is very similar to G. araneoides Pall. [Birula, 1938] while the available material above might have been misidentified, since no $G$. turcmenicus had earlier been recorded from Azerbaijan.

Galeodes turkestanus Kraepelin, 1899

MATERIAL. No-87. 2 우, Azerbaijan, Fizuli, near Garakhanbeyli, 25.VII.[19]78; No-92. 9 90, 6 juv., Fizuli, near Merdinli, 2.IX.[19]78; No-64. 1 ㅇ, Zhdanov (now Beylagan), near Mitabad, 26.VII.[19]78; No-83. 2 우, Fizuli, 28.VIII.[19]78; No-82. 3 우, Fizuli, near Goradis, 22.VII.[19]79, all leg. Sh. Aliyev.

DISTRIBUTION. The plain parts of Uzbekistan from the southern Kizil-kum Desert to the Syr-Dar'ya River [Birulya, 1938].

REMARKS. This species from saltwort habitats, originally described as a subspecies of $G$. araneoides, is quite different from the latter at least in male characters, mainly by the shape of the flag and the presence of ctenidia [Kraepelin, 1899; Birula, 1937]. Since no G. turkestanus has previously been recorded from Azerbaijan, the identity of the above material requires verification.

Genus Paragaleodes Kraepelin, 1899

Paragaleodes melanopygus Birula, 1905

MATERIAL. No-105. 1 \%, Azerbaijan, Talysh, 1979, leg. Sh. Aliyev.

DISTRIBUTION. Azerbaijan (Talysh), northern Iran [Birula, 1938; Hajiyev, 1996].

REMARKS. This species has been described from females alone, while males remain unknown. The ZIN collection contains 3 o from northern Iran and 1 from Azerbaijan (Talysh) [Aliyev, 1984].

Thus, the arachnological collection of the Institute of Zoology of the National Academy of Sciences of Azerbaijan, Baku contains materials on 13 species from 7 genus and 5 families from the order of Solifugae collected on the territory of the Republic. Of these, one species is described as new to science (Galeodes nachitschevanicus); one genus (Gluviopsis) and one species (Gluviopsis nigrocinctus) were first recorded for the fauna of the Caucasus; one genus (Daesia) and one species (Daesia schelkovnikovi), are new to the fauna of the Azerbaijan Republic.

\section{Acknowledgments}

The authors are sincerely grateful to all colleagues from the IZBA, in particular, Dr. Sh.M. Magerramova and Dr. E.F. Huseynov, for the help in collecting the material, and to Dr. O.Kh. Aslanov for the assistance in species identification. Dr. S.I. Golovatch (Moscow) kindly helped us correct the English and publish the paper.

\section{References}

Aliyev Sh.I. 1984. [Solifugae (Arachnida, Solifugae) of Azerbaijan]. PhD Abstract. Kiev. 24 p. [In Russian]

Aliyev Sh.I. 1985. [A new solpugid species of the family Galeodidae (Solifugae) from Azerbaijan] // Zoologicheskii zhurnal. Vol.64. No.7. P.1100-1102 [in Russian]

Aliyev Sh.I., Hajiyev A.T. 1983. [Solifugae (Arachnida, Solifugae) of Azerbaijan] // Izvestiya akademii nauk Azerbaidzhanskoi SSR, Ser. Biol. No.54. P.43-46 [in Russian].

Birula A.A. 1912. [On the distribution of common salpuga (Galeodes araneoides Pallas) in the southern and southeastern parts of European Russia] // Russkoe entomologicheskoe obozrenie. Vol.12. No.2. P.296-312 [in Russian].

Birula A.A. 1937. [On two new species of solifugids (Solifuga) from Turkmenistan] // Trudy Soveta po Izucheniyu Proizvoditel'nykh Sil, Seriya Turkmenskaya. Vol.9. P. 305-314 [in Russian]

Byalynitskiy-Birula A.A. 1938. [Paukoobraznye. Falangi (Solifuga)] Arachnids. Solpugida (Solifuga) // Fauna SSSR. Nov.Ser.17. Paukoobraznye. Vol.1. No.3. Moscow-Leningrad: AN SSSR. 178 p. [In Russian]

Gromov A.V. 1998. Solpugids (Arachnida: Solifugae) of Turkmenistan // Arthropoda Selecta. Vol.7. P.179-188.

Hajiyev A.T. 1996. [Order Solifuga] // Fauna of Azerbaijan. T.2. Phylum of arthropods. Baku: Elm. P.47-49 [in Russian].

Kraepelin K. 1899. Zur Systematik der Solifugen // Mitteilungen aus dem Naturhistorischen Museum in Hamburg. Jg.16. S.197259.

Turk F.A. 1960. On some sundry species of solifugids in the collection of the Hebrew University of Jerusalem // Journal of Zoology. Vol. 135. P. 105-124.

Responsible editor K.G. Mikhailov 